\title{
Tax Service Quality In Increasing Taxpayer Compliance In The Cirebon Satu Pratama Office
}

\author{
${ }^{1 \text { st }}$ Susi Sugiyarsi $1^{*},{ }^{2 \text { nd }}$ Endang Larasati ${ }^{2},{ }^{3 r d}$ Sri Suwitri ${ }^{3},{ }^{4 \text { th }} \mathrm{Ngatno}^{4}$ \\ \{ ssugiyarisih@gmail.com ${ }^{1}$, sri.suwitri@yahoo.co.id ${ }^{2}$, larasati57@ymail.com ${ }^{3}$,ngatrno@gmail.com $\left.{ }^{4}\right\}$ \\ Business Administration, Faculty of Social and Political Sciences, Universitas 17 Agustus 1945 Cirebon $^{1}$ \\ Public Administration, Faculty of Social and Political Sciences, UNDIP Semarang ${ }^{2}$ \\ Public Administration, Faculty of Social and Political Sciences, UNTIDAR Magelang ${ }^{3}$ \\ Business Administration, Faculty of Social and Political, UNDIP Semarang ${ }^{4}$
}

\begin{abstract}
The public as taxpayers always observes the quality provided by tax service administering officers. The quality of service can be seen from officers' professionalism in providing services according to taxpayers' demands. Public service providers have not optimally felt and understood the taxpayer public's wishes appropriately. This study aims to determine the quality of tax services at the Cirebon Satu Pratama Tax Office. Tax compliance is one of the things that are indispensable in tax collection. By adhering to the principle of justice to achieve compliance, the tax laws should balance the government's power or authority to implement the tax system. The quality of tax services' design is assessed from equality, justice, loyalty, and responsibility. This research uses qualitative methods with data collection techniques through observation, interviews, and documentation studies in obtaining data and information. The quality of tax services has not fully met the demands of taxpayers. Suppose the government can show the benefits of the tax system. In that case, it is inevitable that the public will carry out tax obligations properly following tax laws and will increasingly achieve expectations if it is balanced with creativity, innovation, and commitment from all tax service providers prima so that it can encourage all elements of the public taxpayers to increase trust and grow compliance to pay taxes, as a fulfillment of everyday needs and a caring attitude for others. Hence, it is possible that taxes can treat people more voluntarily in fulfilling obligations to the state for the nation's welfare.
\end{abstract}

Keywords: Quality, Tax, Service, Compliance, Tax Officer

\section{Introduction}

In recent years, the field of international taxation has become increasingly prominent in political and public discourse, both on the national and international stage (Gunn et al., 2020: 1). Taxes are a large revenue source and a source of national financing that will benefit the government and the general public. Improving services can be done by improving the quality and technical capacity of employees in the taxation sector. Taxpayer awareness is a factor in the level of taxpayer compliance in complying with tax obligations.

Legal compliance in taxation means the condition of taxpayers who exercise their rights and obligations in a disciplined manner following applicable tax laws and procedures (Soemitro, 1991: 94). Hom (1999: 131) states that compliance in taxation is the level to which taxpayers comply with tax laws. Then Hasseldine (in Nasucha, 2004: 131) says that: Compliance is the 
reporting of all registered taxpayer assets at the specified time and the return of an accurate tax liability report, following the entry code, regulations, and application of court decisions at the time of recording[6].

According to Salamun (1993: 185) states that: "Compliance is the fulfillment of tax obligations (starting from calculating, collecting, deducting, depositing, to reporting tax obligations) by taxpayers following applicable tax laws and regulations. Meanwhile, Nurmantu (2005: 148) says: "Tax compliance is a condition in which the taxpayer fulfills all tax obligations and exercises his taxation rights.

Being an independent nation, the government must increase state revenue, one of which is from taxes. An independent nation cannot be separated from its people's role, and administratively and operationally. It still demands the Directorate General of Taxes' ability to achieve revenue targets as expected. The government hopes to encourage a sense of responsibility and provide quality services to the community.

The obligation of citizens to pay taxes is contained in the UUD 1945, and Article 23A states that "Taxes and other levies which are forcing for state purposes are regulated by law". The provision of public services by the state to its citizens is a form of transaction between the state and its citizens, and the public wants to see for real what has been done with the tax money they have paid, whether services are running smoothly, are the facilities related to the public interest getting better and paid attention by the government. As stated in Law Number 25 of 2009 concerning public services that: "The state is obliged to serve every citizen and resident to fulfill their basic rights and needs within the framework of public services".

Quality is often defined as anything that satisfies a customer or conforms to mandatory requirements or needs. The benchmarks of the quality of tax services provided for taxes are not yet comparable to taxpayers' expectations. The same treatment for services provided and bureaucratic behavior has not been completely consistent in providing quality services to all parties regardless of political affiliation and social status. So far, taxpayers' tax officer services are primarily known whether taxpayers have submitted their SPT or not, both annual and mass SPT. Large income taxpayers or taxpayers have collected taxes from third parties or have made books according to applicable accounting standards. Thus, the service quality of tax officers for taxpayers includes tax payments that must be paid and SPT reporting to report taxes that have been paid.

To be able to assess the extent to which the quality of services provided by tax officials, there need to be criteria that indicate whether a service is a quality or not. In practice, the quality of service is not so evident about equal treatment for taxpayers who approach the element of justice, especially for a pluralistic society. In reality, the submission of annual SPT has not been able to build public awareness of taxpayers because tax officials' quality of tax services has not yet reached public expectations. The satisfaction of taxpayers in the management of tax revenue by the government is more informed about the level of a diversion than the real evidence of infrastructure development, economic improvement, and social welfare.

Efforts that can be made in increasing taxpayer compliance are by providing good service quality for taxpayers. Improving service quality is expected to increase taxpayer compliance.

Based on the research background presented above, it can be formulated; 1). how is the quality of tax services at the Cirebon Pratama Tax Office, 2) the taxpayer compliance at the Cirebon Pratama Tax Service Office, 3) the tax service quality model and the taxpayer compliance model Cirebon Pratama Office. 
The purpose of this research, in general, is to understand, interpret and analyze opinions in-depth regarding the quality of tax services so that it is expected to provide a new concept for the development of public administration science. 1). Describe and analyze the quality of tax services at the Cirebon Satu Pratama Tax Office, 2) Describe and analyze the factors that contribute to the quality of tax services at the Pratama Tax Office Cirebon Satu. 4). Describe and analyze the model of tax service quality and taxpayer compliance at the Pratama Tax Office Cirebon Satu.

Based on the framework, a working hypothesis can be formulated from the research that: The quality of tax services includes aspects of equality, equity, loyalty, and responsibility and compliance. Then the tax service will be in line with the quality expected by the taxpayer public.

\section{Methodology}

This study aims to describe the empirical phenomenon regarding the quality of tax services at the Pratama Tax Office Cirebon Satu. The object of this research is the quality of tax services at the Pratama Tax Office Cirebon Satu. Simultaneously, the research target is the organization implementing the delivery of tax services, namely the Pratama Tax Service Office Cirebon Satu and individual taxpayers registered at the Pratama Tax Office Cirebon Satu.

Qualitative approaches are used as methods and techniques that further emphasize that the qualitative approach is closely related to the unique nature of social reality and the behavior of officers who carry out a series of tax services for the taxpayer's public.

The unit of analysis in this research is tax officers and individual taxpayers registered at Pratama Tax Service Office Cirebon Satu. They are the executors and direct users of services who have paid taxes from their business results. Tax officers and individual taxpayers are very relevant to be the research object because as tax officers represent the government and taxpayers represent themselves in carrying out their tax obligations and take advantage of their tax rights.

Sources of data in this study are informants, documents, and the phenomenon itself. In this study, the informants were officers who worked at the Cirebon Pratama Tax Office, namely officers from Pratama Tax Service Office Cirebon and individual taxpayers registered in the Pratama Tax Service Office Cirebon area.

Informants' determination was based on preliminary information about the quality of tax services at the Cirebon Satu Pratama Tax Office to collect qualitative data. Informants are people who are used to provide information about the situation and conditions of the research background.

Researchers in conducting research make a sorting between the base informants and the key informants. Base informants are considered capable of providing information in general and can show other people as key informants who can provide more in-depth information.

Individual taxpayers who are made as informants are direct users of Pratama Tax Service Office Cirebon One's services, where they have paid taxes from their business results. Individual taxpayers are very relevant to be the object of research. As taxpayers, they represent themselves in carrying out their tax obligations and taking advantage of their tax rights. Most of the research informants consisted of individual taxpayers who were late and or did not report their annual tax returns. Some others reported the Annual SPT is not on time, and some informants are classified as taxpayers who are always obedient or correct in submitting SPT. 
This study used three data sources: interviews, participant observation, and the use of documents.

Interview questions are asked orally, face to face with the subject or informants in-depth (depth interviewing) to obtain in-depth, complete, and detailed data. To explore informants' thoughts and feelings and find out more about the quality of tax services based on their perspective, searching for information emically, interpreted and analyzed by researchers, giving birth to ethical, researchers' views on data.

The document study is used to extract data from documents including the Cirebon Satu Pratama Tax Office file and those involved in service policies at the Cirebon Satu Pratama Tax Office.

In qualitative research, the sampling technique used was purposive sampling and cluster sampling. Purposive sampling is a technique of sampling data sources with specific considerations. Cluster sampling is a sampling technique when the object under study or the data source is vast. Determining the sample in qualitative research is carried out when the researcher begins to enter the field.

In this study to test the validity of the data and use data triangulation techniques that combine various data collection techniques with triangulation, the researchers collect data while testing the credibility of the data, namely checking the credibility of the data with various data collection techniques and various data sources (Sugiyono, 2011: 330)[8].

\section{Finding And Discussion}

\section{Research Result}

The Pratama Tax Service Office's implementation is based on tax regulations and tax administration that are effective, efficient, and trusted by the public by prioritizing the tax public's interests. This research was conducted to describe and analyze Pratama Tax Service Office Cirebon tax officers' quality of service using four aspects: equality, equity, loyalty, and responsibility.

The quality of tax services is more focused on tax officers' activities or benefits as tax service providers to taxpayers who are obliged to implement them. The quality of tax services is an act or deed that is offered in the name of legislation. It contains the implication that tax service activities are organized by service providers in implementing provisions based on regulations to capture satisfaction. This depends on the availability of accompanying services, such as convenience, clarity, speed, accuracy, friendliness, and comfort.

The provision of tax services to the public, taxpayers, does not reduce others' rights to get the same service, so that the tax service process is an interaction that occurs, either between people or people with machines that can lead to satisfaction for those who receive services. So quality tax service is a process of achieving results from activities carried out effectively to establish better relations between tax officials and taxpayers.

Tax officers' quality of tax services must always focus on taxpayers as service recipients (customer-focused quality). Thus, tax service products are designed, produced, and officers to improve their service quality. To fulfill taxpayers' wishes as recipients of government services, officers rarely provide taxpayers socialization. The socialization in question is regarding taxation service procedures designed to be as simple as possible and communicated directly to the taxpayers regarding submission, service handling, delivery of service results, and service 
complaints. Officers are sometimes only open about terms of service and closed about calculating service fees and turnaround times.

Based on the observations and interviews from informants on the statement of the aspect of justice (equity), tax services at the Cirebon Satu Pratama Tax Office still need to be improved in providing fair services (equity). Informants think tax services require attention in terms of justice, and seen from the neutrality of tax service officers in treating taxpayers and honesty, not all of them are balanced with sincerity in providing quality services at the Cirebon Satu Pratama Tax Service Office.

The rapid development of technology impacts the tax administration system, resulting in an online tax system that is of great concern globally (Mustapha \& Obid, 2015: 1). The Pratama Cirebon Satu Tax Office, responding to the improved quality of tax services, has taken management reform steps, including by providing services online. Service procedures have become faster, more precise, and accurate. Improving human resources through education and training, including tax modernization, and improving the community's facilities needed for smooth service. This is like a change in organizational structure regarding the Minister of Finance Decree No. 443 / KMK.01 / 2001. Changing the paradigm of public services does not appear to be a simple problem. The implementation of administrative reform is a comprehensive issue. Factors such as organizational climate, workability, and leadership style are important factors that need to be studied, especially about improving the quality of tax services.

\section{Result Discussion}

The quality of tax services' design is an order of visualization of an idea as a guide that cannot only be assessed from the point of view of the Tax Service Office but must be viewed from the taxpayer's assessment. In this design, the quality of tax services will not only be seen in terms of the opinion of Martin Jr. in (Islamy, 2001: 24) 4 elements; equality, equity, loyalty, and responsibility but other aspects that determine and enhance the achievement[4].

After describing the informant's response to each statement item, both based on the information results of tax service provider officers and taxpayers, the responses can be interpreted regarding the quality of tax services as a whole. It seems that tax service provider informants' response regarding the quality of tax services almost provides positive information because they always protect themselves in the name of rules and regulations.

Good service for taxpayers is needed, equality, fairness, and openness in implementing tax regulations, to increase voluntary taxpayer compliance. So, tax organizations' quality services can build taxpayer compliance if the commitment is used as one of the guidelines for achieving taxpayers' expectations in the Cirebon Satu Pratama Tax Office area.

Commitment to quality service is one of the main principles in tax collection as a manifestation of state obligations. Even though tax reform has been carried out, namely the application of self-assessment where taxpayers are given the confidence to carry out their own tax obligations, starting from their own income calculation, self-calculating the tax owed, paying their own tax payable, and self-reporting the fulfillment of their tax obligations, even so, taxpayers must be still honest and always stick to the provisions of the applicable tax laws.

Tax compliance is indispensable in tax collection by adhering to the principle of justice to achieve compliance so that tax obligations will be carried out smoothly and impact optimal tax revenue at the Cirebon Satu Pratama Tax Service Office.

If the government can show the benefits of the taxation system, the public certainly wants to properly carry out their tax obligations according to the tax laws. For this reason, it fits for the government to improve the taxation system, not only based on tax regulations but also on the benefits of tax obligations that the public will carry out. 
Fair treatment for the taxpayer public by not differentiating the tax paid size shows that tax officers are increasingly fair in providing tax services at the Cirebon Satu Pratama Tax Office.

The primary data from the research results in the field are in the form of interviews as follows: "Justice always refers to the spirit of tax service officers who do everything they can, to be honest, correct and be straight on the expectations of the taxpayers' public. Tax service administrators uphold ethical values in the moral sphere by paying more attention to the public's wishes of taxpayers above their interests. According to applicable regulations, the fairness of officers on tax service regulations is more directed at efforts to orderly manage tax administration and management, file management, work motto, and division of duties. (Results of interviews with informants on 26 November 2019).

From the point of view of responsibility, the results of the interview are as follows: "Since the beginning, tax service administrators have prepared themselves to accept responsibilities with various risks during the implementation of tax services for the taxpayer public" (Results of interviews with informants on 18 September 2019)

Tax compliance is implementing the obligation to deposit and report the amount of tax owed by tax regulations. Decisions expected in the self-assessment system are voluntary compliance and not enforce compliance.

Table 1. Taxpayer Compliance Statistics of Cirebon Satu Pratama Tax Service Office

\begin{tabular}{lcrc}
\hline & $\mathbf{2 0 1 6}$ & $\mathbf{2 0 1 7}$ & $\mathbf{2 0 1 8}$ \\
\hline 2. Registered Taxpayers & 134.188 & 29.518 & 31.243 \\
• Institution & 8.128 & 3.199 & 3.192 \\
• Non Employee & 13.166 & 4.439 & 6.528 \\
• Employee & 112.894 & 21.880 & 21.523 \\
& & & \\
& $\mathbf{2 0 1 6}$ & $\mathbf{2 0 1 7}$ & $\mathbf{2 0 1 8}$ \\
3. Letter of Notification & 28.026 & 27.670 & 29.939 \\
Relaisation & & & \\
- Institution & 2.069 & 2.069 & 2.220 \\
• Non Employee & 3.830 & 4.240 & 4.693 \\
• Employee & 22.127 & 21.361 & 23.026 \\
\hline \multicolumn{2}{l}{ Source: Data Processing from Cirebon Satu Pratama Tax Office } \\
\hline
\end{tabular}


Table 2. Formal Compliance Indicators Based on Law Number 282009 Concerning KUP

\begin{tabular}{|c|c|c|c|}
\hline No & Article & Subject & \begin{tabular}{|l} 
Tax Provisions \\
\end{tabular} \\
\hline 1. & $\begin{array}{l}2 \text { Par. } \\
\text { (1) }\end{array}$ & $\begin{array}{l}\text { Registration and } \\
\text { Confirmation }\end{array}$ & $\begin{array}{l}\text { Every tax that has met subjective and objective } \\
\text { requirements following the provisions of tax laws and } \\
\text { regulations is obliged to register at the Office of the } \\
\text { Directorate General of Taxes, whose working area } \\
\text { includes the residence or domicile of the taxpayer and is } \\
\text { given a tax identification number. }\end{array}$ \\
\hline 2. & $\begin{array}{l}2 \text { Par. } \\
(2)\end{array}$ & $\begin{array}{l}\text { Registration and } \\
\text { Confirmation }\end{array}$ & $\begin{array}{l}\text { Based on the } 1984 \text { value-added tax law and its } \\
\text { amendments, every taxpayer as an entrepreneur who is } \\
\text { subject to tax is obliged to report his business to the } \\
\text { office of the Directorate General of Taxes, whose working } \\
\text { area includes the residence or domicile of the } \\
\text { entrepreneur to be confirmed as a taxable entrepreneur. }\end{array}$ \\
\hline 3. & $\begin{array}{l}2 \text { Par. } \\
\text { (3) }\end{array}$ & $\begin{array}{l}\text { Obligation of } \\
\text { Delivery Tax } \\
\text { Letter } \\
\text { Notification }\end{array}$ & $\begin{array}{l}\text { Each taxpayer fills in the notification letter correctly, } \\
\text { completely and clearly in Indonesian using Latin letters, } \\
\text { Arabic numerals, the rupiah currency unit, and signs and } \\
\text { submits it to the Office of the Directorate General of } \\
\text { Taxes where the Taxpayer is registered or confirmed or } \\
\text { other places determined by the Directorate General of } \\
\text { Tax. }\end{array}$ \\
\hline 4. & $\begin{array}{l}2 \text { Par. } \\
\text { (4) }\end{array}$ & $\begin{array}{l}\text { The Deadline of } \\
\text { Submitting Tax } \\
\text { Letter } \\
\text { Notification }\end{array}$ & $\begin{array}{l}\text { The deadline for submitting notification letters is: } \\
\text { a. For period notification letters, the longest } 20 \text { (twenty) } \\
\text { days after the end of the tax period. } \\
\text { b. For annual tax returns OP taxpayer income, no later } \\
\text { than } 3 \text { (three) months after the end of the tax year, or } \\
\text { c. For annual tax returns, the income of corporate } \\
\text { taxpayers } 4 \\
\text { (four) months after the end of the tax year. }\end{array}$ \\
\hline 5. & $\begin{array}{l}2 \text { Par. } \\
\text { (5) }\end{array}$ & $\begin{array}{l}\text { Tax Payment and } \\
\text { Deposit }\end{array}$ & $\begin{array}{l}\text { The Minister of Finance determines the due date for } \\
\text { payment and payment of taxes payable for a tax period or } \\
\text { period for each tax type, no later than } 15 \text { (fifteen) days } \\
\text { after the time the tax becomes due or the end of the tax } \\
\text { period. }\end{array}$ \\
\hline
\end{tabular}

Source: Cirebon Satu Pratama Tax Service Office (2019) 


\section{Conclusion}

Demands for the quality of tax services from the aspects of equality, equity, loyalty, and responsibility have met taxpayers' expectations. However, they are always criticized by the taxpayers' public, to increase taxpayer compliance in terms of reporting the Annual Tax Return needs to be improved. This is intended to achieve the target expected by the Cirebon Satu Pratama Tax Office.

The equality of taxpayer services carried out, both primary and secondary, requires a perfect service system for taxpayers. This is to increase bureaucratic transparency in serving taxpayers.

The equity aspect shows a neutral attitude and actions for taxpayers to be treated equally in social and economic values, thereby increasing taxpayer public compliance.

The loyalty aspect is measured by officers' loyalty of services to taxpayers, obedience to taxation laws, law, leadership, co-workers, and loyalty to work, which has been seen at the Cirebon Satu Pratama Tax Office.

Meanwhile, the assessment of responsibility is measured by the readiness to accept responsibility, officers' ability to serve taxpayers, the ease of contacting officers to prioritize taxpayers' interests, responsiveness to taxpayer problems and complaints, and providing information to taxpayers.

Evaluating and developing a service system that is transparent, online, or using a selfassessment system so that it can be easily accessed quickly and accurately, optimizes technology facilities, provides convenience to taxpayers, involves experts, and opens the aspirations of taxpayers.

The findings in the field indicate that the quality of tax services will be more efficient and effective when commitments in the aspects of equality, equity, loyalty, and responsibility are enforced for balance, thus encouraging the achievement of voluntary compliance from the taxpayer public. The commitment must be held firmly by both parties, namely tax officials and taxpayers. Tax officers must commit to serve taxpayers following the tax officer's code of ethics. Taxpayers must have a high commitment in calculating, paying, and reporting taxes; they must pay honestly, correctly, entirely, and on time.

\section{References}

[1] Gunn, A. F., Koch, D. J., \& Weyzig, F. (2020). A methodology to measure the quality of tax avoidance case studies: Findings from the Netherlands. Journal of International $\begin{array}{llll}\text { Accounting, } \quad \text { Auditing } \quad \text { and } & \text { Taxation, } & 390318 .\end{array}$ https://doi.org/10.1016/j.intaccaudtax.2020.100318

[2] Hardiyansyah, 2018. Kualitas Pelayanan Publik. Yogyakarta. Gava Media Ibrahim, Amin. 2008. Teori dan Konsep Pelayanan Publik Serta Implikasinya. Bandung. Mandar Maju

[3] Kurniawan, Agung. 2005. Transformasi Pelayanan Publik. Yogyakarta, Pembaruan.

[4] Martin Jr. dalam Islamy,2001. Agenda Kebijakan Reformasi Administrasi Negara. Jurnal Administrasi Negara Vol.II no.1 September 2001: 13-20.

[5] Mustapha, B., \& Obid, S. N. B. S. (2015). Tax Service Quality: The Mediating Effect of Perceived Ease of Use of the Online Tax System. Procedia - Social and Behavioral Sciences, 172, 2-9. https://doi.org/10.1016/j.sbspro.2015.01.328 
[6] Nasucha. Chaizi, 2004. Reformasi administrasi Publik dan Praktik, Jakarta: Penerbit PT Gramedia Widiasarana Indonesia.

[7] Resmi. Siti. 2009. Perpajakan Teori dan Kasus. Edisi Kelima.jakarta: Salemba Empat

[8] Sugiyono, 2018, Metode Penelitian Kualitatif. Bandung Alfabeta. Sinambela, dkk 2006. Reformasi Pelayanan Publik, Teori Kebijakan dan Implementasi, Jakarta: Bumi Aksara.

[9] Keputusan Menteri Keuangan RI Nomor 443/KMK.01/2001 tentang Organisasi danTata Kerja Kantor Wilayah Direktorat Jenderal Pajak, Kantor Pelayanan Pajak, Kantor Pelayanan Pajak Bumi dan Bangunan, Kantor Pemeriksaan dan Penyidikan Pajak, dan Kantor Penyuluhan dan Pengamatan Potensi Perpajakan. 